\title{
Girls on the Run: Impact of a Physical Activity Youth Development Program on Psychosocial and Behavioral Outcomes
}

\author{
Maureen R. Weiss \\ University of Minnesota \\ Lindsay E. Kipp \\ Texas State University \\ Alison Phillips Reichter \\ University of lowa \\ Sarah M. Espinoza \\ University of Minnesota \\ Nicole D. Bolter \\ San Francisco State University
}

\begin{abstract}
Purpose: Girls on the Run is an after-school physical activity-based positive youth development program designed to enhance girls' social, psychological, and physical development. We evaluated the effectiveness of the program by employing a longitudinal design and mixed methods. Methods: Girls ( $\mathrm{N}=203$; aged 8-11 y) completed survey measures of positive youth development constructs (competence, confidence, connection, character, and caring), physical activity, and sedentary behavior prior to, at the end of, and 3 months after the season. Subsamples of girls, coaches, caregivers, and school personnel participated in focus groups. Coaches completed information about their team's community impact project and number of girls who completed the season-ending 5k. Results: The full sample improved in confidence and connection, whereas girls who started below the preseason average showed the greatest gains from preseason to postseason on all measures, and scores were maintained or continued to improve at follow-up. All stakeholders in focus groups corroborated evidence of season-long improvement in social and emotional behaviors and health outcomes. Involvement in the community impact project contributed to girls' growth in character and empathy skills. Conclusion: Findings provide empirical evidence that Girls on the Run is effective in promoting positive youth development, including season-long and lasting change in competence, confidence, connection, character, caring, and physical activity, especially among girls who exhibited lower preseason scores than their peers.
\end{abstract}

Keywords: out-of-school time, evaluation research, community program, children

This manuscript introduces our comprehensive project evaluating the effectiveness of Girls on the Run, a physical activitybased youth development program. Considerable evidence reveals the many health benefits of regular physical activity for children and youth, including cardiorespiratory fitness, bone strength, cognitive functioning, and psychological well-being (4,31). Despite supportive data, a substantial percentage of elementary-age children are not engaged in sufficient activity levels to attain health benefits - at least 60 minutes daily of moderate to vigorous aerobic activity, along with muscle- and bone-strengthening activities at least 3 days per week $(31,39)$. The Physical Activity Guidelines for Americans Midcourse Report (32) and National Physical Activity

Weiss and Espinoza are with University of Minnesota, Minneapolis, MN. Kipp is with Texas State University, San Marcos, TX. Phillips Reichter is with University of Iowa, Iowa City, IA. Bolter is with San Francisco State University, San Francisco, CA. Weiss (mrweiss@umn.edu) is corresponding author.
Plan (29) accentuate the role of schools in contributing to required physical activity levels and consequent health and well-being of youth.

Schools are ideal settings for increasing physical activity, given the large percentage of time children spend at school and inclusion of all socioeconomic and ethnic groups (29,32). Sources for enhancing activity levels include physical education, recess, active transport (eg, biking to school), and after-school sports (11). However, physical education and recess have been eliminated or downsized in many districts, active transport is constrained by perceived safety concerns, and after-school sports emphasize competition that may not satisfy the interests of most children (7). Thus, efforts to increase physical activity in school settings are desirable - during the normal school day and in after-school hours. Given increasing demands on classroom learning, after-school programs have garnered greater interest as a source of increasing physical activity as well as improving social and emotional behaviors and academic performance $(12,21,41)$. 
After-school physical activity programs can be delivered by schoolteachers and instructors of community programs and provide opportunity to nurture partnerships among schools, communities, and families $(12,28)$. Some after-school programs are explicitly designed to promote positive youth development (PYD), including desirable social, psychological, and behavioral outcomes $(43,45)$. PYD is a conceptual framework that emphasizes acquisition of competencies, core values, and healthy behaviors to help youth function effectively in the present and throughout their lifetime $(25,33)$. PYD programs are distinguished by contexts that accentuate psychological and physical safety; appropriate structure; supportive relationships; opportunities for skill building; and integration of family, school, and community efforts, among other features (13). The goals and features of PYD programs are compatible with the American School Health Association's (www. asha.org) core beliefs of promoting holistic well-being of youth by acquiring healthy habits for a lifetime and ensuring safe, nurturing environments that facilitate learning. Thus, physical activity-based PYD (PA-PYD) programs located within school settings, such as Girls on the Run, may be particularly effective for addressing youth physical inactivity and associated psychosocial and behavioral health outcomes $(12,41,43)$.

Youth physical activity researchers have embraced the PYD framework as a means of studying how to promote healthy attitudes and behaviors within an appropriate climate and through guidance by competent instructors $(30,43)$. Studies using correlational designs have uncovered (1) positive relationships between environmental features (eg, mastery motivational climate) and developmental outcomes (eg, prosocial behavior) in community sports programs, and (2) pre-post program improvements in youths' self-perceptions in sport camp settings (eg, 16,38). Fewer intervention and evaluation studies have been conducted but show promise that PA-PYD programs can be particularly effective in improving physical and psychosocial health outcomes $(41,43)$.

Some PA-PYD programs revealed positive outcomes with underserved or vulnerable youth (eg, 1,6). Most studies used prepost designs without a comparison group and did not conduct a follow-up assessment to determine whether season-long improvements were maintained beyond program's end. Other studies evaluated impact of PA-PYD programs, such as Teaching Personal and Social Responsibility (40), The First Tee (42), and a national program in the United Kingdom (2). These studies employed longitudinal designs, comparison groups, and/or multiple methods. More evaluation studies of PA-PYD programs are needed to determine effects on social, psychological, and physical activity outcomes by employing rigorous designs, measures, and procedures (41). Few studies have evaluated PA-PYD programs that forge a partnership between schools and community programs, which is important given the potential for such partnerships to promote positive health outcomes $(29,32)$. Girls on the Run is an after-school community program implemented in school settings and provided opportunity to pursue this goal.

\section{Girls on the Run}

Girls on the Run is primarily a school-based, after-school PA-PYD program $^{1}$ designed to enhance girls' social, psychological, and physical competencies to successfully navigate life experiences. The program uses running and other physical activities as a platform for promoting holistic health outcomes in third- through fifth-grade girls. The mission, "we inspire girls to be joyful, healthy and confident using a fun, experience-based curriculum which creatively integrates running," is accompanied by a vision and core values that accentuate empowering girls to achieve their goals, stand up for self and others, and develop healthy connections with others (www.girlsontherun.org). Girls on the Run collaborates with elementary and middle schools to provide opportunities for all girls interested in participating. The organizational network consists of $>200$ councils serving more than 200,000 girls annually in all 50 states. Since its inception in 1996, over 1.5 million girls have participated in the program, with over $45 \%$ provided scholarship support. The culminating event is completing a 5k, with Girls on the Run hosting over 300 events annually. Girls on the Run was named a leading out-of-school-time social and emotional learning program in the United States (23).

Girls on the Run adopts the Five Cs approach to PYD that targets competence, confidence, connection, character, and caringand a sixth $\mathrm{C}$, contribution, accompanies the Five Cs (25). The program aims to help girls develop social, emotional, and physical competence, feel confident in who they are, create positive connections with peers and adults, develop strength of character, respond to others and oneself with care and compassion, and make a meaningful contribution to community (hereafter we refer to Five Cs +1 ). The 10-week intentional curriculum (90-min lessons twice weekly) that combines physical activity with skill-building opportunities focuses on relevant concepts for 8- to- 11-year-old girls: (1) identity-engaging in self-care and self-awareness, (2) connectedness - selecting and keeping healthy relationships, and (3) empowerment - celebrating and sharing our strengths. Coaches are trained to effectively deliver curricular lessons with emphasis on (1) building supportive and trusting relationships; (2) creating a positive, inclusive environment; and (3) fostering a mastery motivational climate (ie, a focus on self-referenced goals, such as learning and improving).

Preliminary studies of Girls on the Run provide initial evidence of effectiveness $(10,15,27,34)$. These studies were a good start to evaluation but were characterized by some limitations, such as pre-posttest-only designs, small sample sizes, pretest data collected after lessons had begun, not including a retention assessment, measuring constructs that did not align with the program philosophy, and/or having coaches and teachers administer surveys, which could lead to social desirability effects. These initial studies prompted our overarching project goal to evaluate the impact of Girls on the Run on positive youth development using more rigorous methods.

\section{Overall Project Goal and Aim of the Present Study}

The present study is part of a larger project evaluating the effectiveness of Girls on the Run, a PA-PYD program. The 2 primary questions were: (1) Do Girls on the Run participants show improvements from preseason to postseason on PYD (Five Cs, physical activity, and sedentary behavior), and retain improvements at follow-up 3 months after season's end? (2) Do Girls on the Run participants differ from a matched comparison group at postseason on life skills learning and transfer? In this article, we focus on methods, results, and interpretation of the longitudinal component (question 1). This study aim extended past evaluation research in several important ways. First, our study design was compatible with the Five Cs philosophy of Girls on the Run, which meant purposefully selecting constructs and measures that align with program goals. Second, we assessed change in relevant constructs prior to the season, immediately after the season, and 3 months following season's end to determine whether any improvements from 
preseason to postseason were maintained beyond exposure to coaches and lessons. Third, we used quantitative (survey) and qualitative (focus groups) methods to provide numbers and narrative to comprehensively seek evidence of effectiveness. Finally, we sought perspectives from multiple stakeholders-girls, coaches, caregivers, and school personnel-to identify converging and diverging evidence of program impact.

\section{Methods}

Quantitative survey methods were used to assess the Five Cs, physical activity, and sedentary behavior, and qualitative focus groups were conducted to further gather information about program impact. Coaches completed an online survey to describe their team's community impact project and documented number of girls completing the season-culminating $5 \mathrm{k}$.

\section{Participants: Survey}

Girls representing 3 councils in different geographical regions of the Girls on the Run network completed a survey comprising study measures. In collaboration with the National office, councils were selected based on several inclusion criteria: (1) at least 5 years of delivering the curriculum as intended, (2) new and returning coaches required to complete mandatory training each year, (3) council conducts site visits to ensure that coaches deliver the curriculum as intended, (4) council director has a good working relationship with schools, and (5) council includes participants diverse in race, ethnicity, and socioeconomic status. Council directors were consulted on selecting schools and teams from which girls would be drawn for the study. Inclusion criteria for schools and teams were: (1) coaches having a good relationship with school personnel, (2) coaches who were also teachers in the school, (3) teams with returning coaches who have consistently delivered the curriculum as intended, (4) providing a site liaison to assist with study procedures, and (5) diverse in race, ethnicity, and socioeconomic status.

A total of 215 Girls on the Run participants in 14 schools across 3 cities and 3 states in different geographical regions provided complete preseason and postseason data, and we retained $203(94.4 \%)$ at follow-up 3 months after season's end (mean age $=$ $9.8 \mathrm{y}, \mathrm{SD}=0.78)$. Girls self-identified as white $(65.6 \%)$, Latina (10.7\%), African American (8.8\%), multiracial (7.0\%), Native American (2.3\%), Asian (1.4\%), and other (4.2\%).

\section{Participants: Focus Group Interviews}

Girls $(n=17)$, coaches $(n=19)$, caregivers $(n=10)$, and school personnel $(n=14)$ volunteered to participate in focus groups after the season ended. Focus groups were separately conducted for each stakeholder in each of the 3 councils, and interviews by stakeholder were combined to analyze responses. Girls averaged 9.5 years old and included third, fourth, and fifth graders. Seven girls selfidentified as African American, 6 as white, and the rest as Latina, Asian, multiracial, and other. Coaches were female, ranged in age from 25 to 63 years (mean $=38.1$ ), and served as an assistant or head coach in Girls on the Run for 1 to 14 years $($ mean =5.1). Seventeen were white and 2 were African American. Sixteen coaches were classroom or specialty teachers, with others listing retired teacher, educator, and community school director. Caregivers were mothers and grandmothers and ranged in age from 29 to 59 years $($ mean $=44.0)$. Six identified as white and 4 as African
American. The 14 school personnel were female, ranged in age from 24 to 61 years (mean $=41.6$ ), and worked at their school for 1 to 28 years (mean $=11.0)$. Eight identified as white, 4 as African American, 1 as multiracial, and 1 as other. Ten of 14 were teachers, with others listing educator, occupational therapist, and parent coordinator.

\section{Survey Instruments}

We selected valid, reliable, and developmentally appropriate measures that aligned with the Five Cs philosophy of Girls on the Run. Selection was informed by Geldhof et al's $(17,18)$ measures of PYD, research with similar-aged samples (41), and pilot studies with Girls on the Run participants. Table 1 provides relevant information for each of the Five Cs-definition, assessment, instrument (including original citation and range of scores), and sample items. We assessed physical activity (number of days per week of MVPA $\geq 60 \mathrm{~min}$ ) and sedentary behavior (number of hours watching TV and playing video/computer games on a school day) with items from the Youth Risk Behavior Survey (8). Demographic items were also completed.

\section{Focus Group Interviews}

Separate, parallel interview guides were prepared for youth, coaches, caregivers, and school personnel. Researchers derived questions to tap into what, how, and why girls may have learned various skills, attitudes, and behaviors through participating in Girls on the Run. Interview guides and procedures for conducting focus groups were based on recommendations by Krueger and Casey (24). A researcher conducted each interview, aided by an assistant moderator who distributed consent forms and summarized key points at the end of the interview. Interviews began with the moderator's introduction, statement of purpose, and guidelines for the session. An icebreaker followed along with a few general questions (eg, "What are some of the things you like about participating in Girls on the Run?"). Main questions included what changes in social, emotional, and physical behaviors might have occurred, and whether and how girls learned healthy habits at Girls on the Run. The interview concluded with wrap-up questions (eg, school personnel: "What would you tell other schools about Girls on the Run?'). Participants completed written demographic items after the interview.

\section{Coaches' Online Survey}

Coaches completed an online survey describing their team's community impact project, which serves as an index of contribution in the Five $C s+1$ framework. Items included: (1) What group of people or cause was the focus of your community project? (2) What project did your team design and implement to help this group or cause? (3) Briefly describe your team's project. (4) Share any additional thoughts about your team's project. Responses were integrated with focus group commentary to provide a parsimonious view of girls' learning and experience.

\section{5k Season-Ending Event}

The culminating physical activity goal is completing a $5 \mathrm{k}$, which girls train for throughout the season, representing an index of physical competence attained from participating (45). The $5 \mathrm{k}$ takes place in a fun and noncompetitive atmosphere, together with all teams in the same Girls on the Run council. Following the 5k event for each council, the principal investigator (PI) prompted coaches 
Table 1 Definitions, Assessments, Instruments, and Sample Items for Survey PYD Constructs (Five Cs)

\begin{tabular}{|c|c|c|c|c|}
\hline PYD construct & Definition (18) & Assessment & Instrument & Sample items \\
\hline Competence & $\begin{array}{l}\text { Positive views of one's actions in } \\
\text { domain-specific areas including } \\
\text { physical, social, and academic }\end{array}$ & $\begin{array}{l}\text { Perceived physical } \\
\text { competence ( } 4 \text { items) } \\
\text { Perceived social } \\
\text { competence ( } 4 \text { items) }\end{array}$ & $\begin{array}{l}\text { Self-Perception Profile } \\
\text { for Children (19) } \\
\text { (scores range: } 1-4 \text { ) }\end{array}$ & $\begin{array}{l}\text { Some kids do very well at all kinds of } \\
\text { physical activities BUT Other kids don't } \\
\text { feel they are very good when it comes to } \\
\text { physical activities } \\
\text { Some kids find it hard to make friends BUT } \\
\text { Other kids find it pretty easy to make friends }\end{array}$ \\
\hline Confidence & $\begin{array}{l}\text { A sense of positive self-worth; } \\
\text { global self-regard as opposed to } \\
\text { domain-specific beliefs }\end{array}$ & $\begin{array}{l}\text { Perceived physical } \\
\text { appearance ( } 4 \text { items) } \\
\text { Global self-esteem } \\
\text { (4 items) }\end{array}$ & $\begin{array}{l}\text { Self-Perception Profile } \\
\text { for Children (19) } \\
\text { (scores range: } 1-4)\end{array}$ & $\begin{array}{l}\text { Some kids are happy with the way they look } \\
\text { BUT Other kids are not happy with the way } \\
\text { they look } \\
\text { Some kids are happy with themselves as a } \\
\text { person BUT Other kids are not happy with } \\
\text { themselves as a person }\end{array}$ \\
\hline Connection & $\begin{array}{l}\text { Positive bonds with and exchanges } \\
\text { between the individual and peers, } \\
\text { family, school, and community }\end{array}$ & $\begin{array}{l}\text { Perceived classmate } \\
\text { support ( } 4 \text { items) }\end{array}$ & $\begin{array}{l}\text { Social Support Scale } \\
\text { for Children }(20) \\
\text { (scores range: } 1-4)\end{array}$ & $\begin{array}{l}\text { Some kids have classmates who like them } \\
\text { the way they are BUT Other kids have } \\
\text { classmates who wish they were different }\end{array}$ \\
\hline Character & $\begin{array}{l}\text { Respect for societal rules, } \\
\text { possessing standards for correct } \\
\text { behaviors, a sense of right and } \\
\text { wrong, and integrity }\end{array}$ & $\begin{array}{l}\text { Perceived social } \\
\text { responsibility } \\
(4 \text { items })\end{array}$ & $\begin{array}{l}\text { Personal and Social } \\
\text { Responsibility Ques- } \\
\text { tionnaire (26) (scores } \\
\text { range: } 1-6)\end{array}$ & $\begin{array}{l}\text { I respect others; I help others; I am kind to } \\
\text { others }\end{array}$ \\
\hline Caring & $\begin{array}{l}\text { A sense of sympathy and empathy } \\
\text { for others }\end{array}$ & $\begin{array}{l}\text { Perceived empathy/ } \\
\text { sympathy ( } 4 \text { items) }\end{array}$ & $\begin{array}{l}\text { Sympathy Scale (14) } \\
\text { (scores range: } 1-6)\end{array}$ & $\begin{array}{l}\text { I feel upset when I see a girl getting her } \\
\text { feelings hurt }\end{array}$ \\
\hline
\end{tabular}

Abbreviation: PYD, positive youth development. Note: Higher scores correspond to more favorable responses on each of the Five Cs. Additional details about survey questions/items, response format, and psychometrics for each measure can be found in the citations listed.

to identify which girls on their roster did and did not participate, and a percentage was calculated of the 203 girls in our longitudinal sample completing the $5 \mathrm{k}$ event.

\section{Procedure}

We obtained approval to conduct the study from University of Minnesota's institutional review board and secured youth assent and parental consent, as well as consent from adult participants prior to each data collection. A pilot study was conducted with 44 girls (mean age $=9.1 \mathrm{y}$ ) participating at a Girls on the Run council not involved in the main study. The purpose was to gauge comprehension of items and determine length of time needed to complete the survey. Girls easily understood all items and response formats and completed the survey within 30 minutes.

The PI made site visits to all schools prior to the first data collection. She met with school principals and site liaisons to explain study procedures, distributed a letter to send parents describing the study, and scheduled the survey date. The first data collection occurred prior to the start of the season. Researchers administered the survey to groups of girls in classrooms, libraries, or cafeterias. This process was repeated for the second data collection right after the season and for the third assessment 3 months after season's end. Three months allowed a reasonable time to assess retention after lessons concluded and avoided a confound of girls being exposed to further lessons in the upcoming season. Girls completed the survey within 30 minutes. Focus groups were conducted right after the season ended in locations convenient for participants in each council. Interviews lasted on average 45 minutes for girls and school personnel and 60 minutes for coaches and caregivers.

\section{Data Analysis}

First, measures at each time point were evaluated for validity and reliability using confirmatory factor analysis, a rigorous procedure to determine measurement integrity based on model fit and factor loadings. Second, multivariate repeated-measures analyses of variance were conducted to determine if the Five Cs and physical activity improved, and sedentary behavior declined, from preseason to postseason and remained stable at follow-up. Statistically significant multivariate values were followed by univariate time comparisons. As a secondary analysis, we also observed pre to post to follow-up trends for girls who scored below the preseason average on a particular variable (eg, $<2.88$ on perceived physical competence) or above the preseason average for sedentary behavior (eg, $>1.14$ for TV watching), based on research showing youth who scored lower on key variables (eg, self-esteem) at preseason demonstrated the greatest gains $(1,36)$. Effect size was assessed using Cohen $d(9)$ : $\geq 0.20=$ small, $\geq 0.50=$ medium, and $\geq 0.80=$ large effects.

For focus groups, deductive and inductive content analyses were used to identify narrative that represented skills and behaviors attained through participation. Deductive analysis was used for questions guided by specific content in the curriculum, whereas inductive analysis enabled themes to emerge. Transcriptions were analyzed separately by stakeholder. We followed data analysis guidelines recommended by qualitative sources $(\mathrm{eg}, 24)$ and used in PA-PYD research (eg, 44). Researchers with training and experience in qualitative methods independently read transcriptions and coded narrative to serve as data units. They met to discuss and reach consensus on data units to include in subsequent steps. Data units with similar meaning were combined to form lowerorder themes and labeled to describe meaning. Lower-order themes were reviewed to determine if they formed more parsimonious higher-order themes, which were labeled for similar meaning.

\section{Results}

We systematically report findings from survey data, focus groups, community impact project, and season-culminating $5 \mathrm{k}$. 


\section{Survey Findings: Preseason to Postseason to Follow-Up}

Based on confirmatory factor analysis, all multi-item measures showed good-fitting factor models (comparative fit index and goodness-of-fit index $>.95$ ) and statistically significant factor loadings, indicating strong psychometric properties. Based on multivariate repeated-measures analyses of variance for the full sample $(\mathrm{N}=203)$, statistically significant improvements emerged for confidence and connection: (1) perceived physical appearance (preseason to follow-up and postseason to follow-up), (2) global self-esteem (postseason to follow-up), and (3) perceived classmate support (postseason to follow-up). ${ }^{2}$ Girls improved in how happy they feel with the way they look, how much they like the kind of person they are, and how much they think classmates like them. Effect sizes were small for significant pre to follow-up and post to follow-up differences $(d=0.12-0.28)$. Table 2 displays means (SDs) at pre, post, and follow-up.

Girls scoring below the preseason average on a given variable (eg, $<2.88$ on perceived physical competence) showed statistically significant improvement from preseason to postseason on all variables representing the Five $C s$ and physical activity. Girls who scored above the preseason average on watching TV and playing video/computer games (ie, sedentary behavior) showed a significant decline. ${ }^{3}$ Scores remained stable from postseason to followup, indicating maintenance of preseason to postseason gains, and some scores continued to improve from post to follow-up (ie, perceived social competence, physical appearance, and classmate support, and global self-esteem). Effect sizes for all statistically significant variables ranged from small to large for preseason to postseason $(d=0.32-1.26$; mean $=0.61)$, medium to large for pre to follow-up $(d=0.52-1.13$; mean $=0.76)$, and small to medium for post to follow-up $(d=0.22-0.59$; mean $=0.38)$. Table 2 displays means (SDs) at pre, post, and follow-up.

\section{Focus Group Findings}

Qualitative data supplemented quantitative findings to shed insight on girls' growth and development as a result of participating in Girls on the Run.
Changes in Girls' Behaviors. Girls, coaches, caregivers, and school personnel discussed whether they observed changes in girls' social, emotional, and physical behaviors. Similar higher-order themes emerged for all stakeholders: increased positive emotional behaviors, emotion management, increased positive social behaviors, developing positive social relationships, improved running and motivation to run, standing up for self and others, and setting and accomplishing goals. Lower- by higher-order themes can be seen in Table 3. Results provide evidence that Girls on the Run is having a positive impact on emotional, social, and physical competence (eg, expressing feelings, more outgoing, improved running); confidence (eg, feeling better about self); connection (eg, choosing the right friends); character (eg, acting nicer to others); and caring behaviors (eg, accepting of others).

Samantha ${ }^{4}$ shared, "Before I came to Girls on the Run, I used to like, whenever my friend would tell me to do things, I would just do it for the sake of being their friend ... I used to try and do these things so I could fit in and stay friends with them ... there was this girl and I used to not be nice to her because my friend said, 'oh, I don't like this kid, so you shouldn't' ... After I came to Girls on the Run, I realized that I shouldn't do those things." A coach shared how a girl improved managing her emotions, "We had a girl speak and represent our team (at a banquet) . . . she has always had real anger and temper issues, and would lash out at kids, at adults, there was nobody spared in her path. She got up and spoke about how since she joined Girls on the Run, 'I feel calmer and happier at school' ... it was really awesome to hear a kid be like, 'I feel so much better about myself' and speak to a room of adults about it."

Healthy Habits Learned. Girls, coaches, caregivers, and school personnel discussed whether participating in the program contributed to change in health-related behaviors. Higher-order themes included physical, nutritional, emotional, mental, and social health. Lower- by higher-order themes are seen in Table 4. Girls exclusively referred to changing physical health (eg, more active, run faster) and nutrition (eg, eat healthier food, more veggies/ fruits), whereas coaches, caregivers, and school staff also noted changes in emotional (eg, greater confidence), mental (eg, setting goals), and social health (eg, bonding with girls). Because physical

Table 2 Means (SDs) for Entire Sample and Girls Starting Below the Preseason Mean

\begin{tabular}{|c|c|c|c|c|c|c|}
\hline \multirow[b]{3}{*}{ Variable } & \multicolumn{3}{|c|}{ Entire sample } & \multicolumn{3}{|c|}{ Girls starting below preseason mean* } \\
\hline & \multicolumn{3}{|c|}{ Mean (SD) } & \multicolumn{3}{|c|}{ Mean (SD) } \\
\hline & Pre & Post & Follow-up & Pre & Post & Follow-up \\
\hline Perceived physical competence & $2.88(0.69)$ & $2.92(0.66)$ & $2.93(0.67)$ & $2.28(0.47)$ & $2.61(0.61)^{\mathrm{a}}$ & $2.58(0.60)^{\mathrm{b}}$ \\
\hline Perceived social competence & $3.08(0.77)$ & $3.00(0.72)$ & $3.09(0.72)$ & $2.38(0.60)$ & $2.57(0.72)^{\mathrm{a}}$ & $2.71(0.78)^{\mathrm{b}, \mathrm{c}}$ \\
\hline Perceived physical appearance & $3.19(0.66)$ & $3.23(0.70)$ & $3.32(0.66)^{\mathrm{b}, \mathrm{c}}$ & $2.55(0.49)$ & $2.79(0.77)^{\mathrm{a}}$ & $2.96(0.75)^{\mathrm{b}, \mathrm{c}}$ \\
\hline Global self-esteem & $3.55(0.56)$ & $3.52(0.59)$ & $3.61(0.53)^{\mathrm{c}}$ & $3.01(0.50)$ & $3.22(0.65)^{\mathrm{a}}$ & $3.41(0.63)^{\mathrm{b}, \mathrm{c}}$ \\
\hline Perceived classmate support & $3.17(0.64)$ & $3.09(0.64)$ & $3.26(0.56)^{\mathrm{c}}$ & $2.53(0.48)$ & $2.76(0.67)^{\mathrm{a}}$ & $3.04(0.59)^{\mathrm{b}, \mathrm{c}}$ \\
\hline Perceived social responsibility & $5.30(0.66)$ & $5.36(0.61)$ & $5.34(0.57)$ & $4.81(0.64)$ & $5.12(0.62)^{\mathrm{a}}$ & $5.14(0.60)^{\mathrm{b}}$ \\
\hline Perceived empathy/sympathy & $5.42(0.66)$ & $5.49(0.65)$ & $5.41(0.65)$ & $4.76(0.61)$ & $5.23(0.75)^{\mathrm{a}}$ & $5.15(0.78)^{\mathrm{b}}$ \\
\hline Physical activity, $\mathrm{d} / \mathrm{wk}$ & $4.86(1.71)$ & $4.94(1.87)$ & $4.81(1.89)$ & $3.05(1.03)$ & $4.35(1.86)^{\mathrm{a}}$ & $4.22(2.02)^{\mathrm{b}}$ \\
\hline Watching TV, h/d & $1.14(1.23)$ & $1.27(1.31)$ & $1.25(1.26)$ & $2.84(1.07)$ & $2.23(1.40)^{\mathrm{a}}$ & $2.12(1.49)^{\mathrm{b}}$ \\
\hline Playing video/computer games, $\mathrm{h} / \mathrm{d}$ & $1.12(1.31)$ & $1.24(1.32)$ & $1.26(1.39)$ & $3.12(1.18)$ & $2.50(1.51)^{\mathrm{a}}$ & $2.22(1.69)^{\mathrm{b}}$ \\
\hline
\end{tabular}

Note: $\mathrm{N}=203$ for entire sample. $\mathrm{N}=77$ to 95 for girls starting below the preseason mean for the Five Cs and physical activity. $\mathrm{N}=49$ to 56 for girls scoring above the preseason mean for watching TV and playing video/computer games (sedentary behavior).

${ }^{a}$ Statistically significant change from preseason to postseason. ${ }^{\mathrm{b}}$ Statistically significant change from pre to follow-up. ${ }^{\mathrm{c}}$ Statistically significant change from post to follow-up. *Or starting above the preseason mean for sedentary behaviors. 
Table 3 Focus Group Responses for Changes in Girls' Behaviors as a Result of Participating in Girls on the Run

\begin{tabular}{|c|c|c|c|c|}
\hline $\begin{array}{l}\text { Higher-order } \\
\text { theme }\end{array}$ & $\begin{array}{l}\text { Girls: lower-order } \\
\text { theme }\end{array}$ & $\begin{array}{l}\text { Coaches: } \\
\text { lower-order theme }\end{array}$ & $\begin{array}{l}\text { Caregivers: } \\
\text { lower-order theme }\end{array}$ & $\begin{array}{l}\text { School personnel: } \\
\text { lower-order theme }\end{array}$ \\
\hline $\begin{array}{l}\text { Increased positive } \\
\text { emotional behaviors }\end{array}$ & $\begin{array}{l}\text { - Learn about self } \\
\text { - Live in the moment } \\
\text { - Be positive about self } \\
\text { - Less self-conscious } \\
\text { - Feel better about self } \\
\text { - More self-aware } \\
\text { - Being nonjudgmental }\end{array}$ & $\begin{array}{l}\text { - More confident } \\
\text { - Beauty from within } \\
\text { - Happier in school } \\
\text { - More self-aware } \\
\text { - Feeling empowered } \\
\text { - Feelings of control } \\
\text { - Accepting self }\end{array}$ & $\begin{array}{l}\text { - Improved confidence } \\
\text { - Stronger emotionally } \\
\text { - Setting boundaries } \\
\text { - Expresses feelings } \\
\text { - Loves self } \\
\text { - Can-do attitude } \\
\text { - Proud of achievements }\end{array}$ & $\begin{array}{l}\text { - Opens up more } \\
\text { - More confident } \\
\text { - More positive disposition } \\
\text { - Greater sense of self } \\
\text { - Pride in themselves } \\
\text { - Feeling empowered } \\
\text { - More self-aware }\end{array}$ \\
\hline $\begin{array}{l}\text { Emotion } \\
\text { management }\end{array}$ & $\begin{array}{l}\text { - Managing emotions } \\
\text { - Expressing feelings } \\
\text { - Changing negative } \\
\text { statements to positive } \\
\text { - Think before acting }\end{array}$ & $\begin{array}{l}\text { - Managing anger } \\
\text { - Taking a breather } \\
\text { - Expressing feelings } \\
\text { - Deals with conflict } \\
\text { - More collected/calm }\end{array}$ & $\begin{array}{l}\text { - Calmed herself down } \\
\text { - Expresses feelings } \\
\text { - Emotional control } \\
\text { - Does not internalize } \\
\text { criticism }\end{array}$ & $\begin{array}{l}\text { - Changes negative to positive } \\
\text { statements } \\
\text { - Resolves conflicts } \\
\text { - Communicates calmly } \\
\text { - Deals with negative situations }\end{array}$ \\
\hline $\begin{array}{l}\text { Increased positive } \\
\text { social behaviors }\end{array}$ & $\begin{array}{l}\text { - Considers others' } \\
\text { feelings } \\
\text { - More outgoing } \\
\text { - Act like true self } \\
\text { - Making good choices } \\
\text { - Act nicer to others }\end{array}$ & $\begin{array}{l}\text { - More outgoing } \\
\text { - Being a leader } \\
\text { - Coming out of shell } \\
\text { - Inclusive of others } \\
\text { - Better social skills } \\
\text { - Acting nicer }\end{array}$ & $\begin{array}{l}\text { - Encourages teammates } \\
\text { - More social } \\
\text { - Peer interactions } \\
\text { - More friendly } \\
\text { - Communicates better } \\
\text { - Encourages other kids }\end{array}$ & $\begin{array}{l}\text { - More outgoing } \\
\text { - More inclusive of others } \\
\text { - More comfortable with peers } \\
\text { - Shows greater respect } \\
\text { - More responsible } \\
\text { - Leadership skills }\end{array}$ \\
\hline $\begin{array}{l}\text { Developing positive } \\
\text { social relationships }\end{array}$ & $\begin{array}{l}\text { - Choose right friends } \\
\text { - Improve friendships } \\
\text { - Make new friends }\end{array}$ & $\begin{array}{l}\text { - Less self-centered } \\
\text { - Accepting others } \\
\text { - More inclusive } \\
\text { - Finds positive friends } \\
\text { - Supporting others }\end{array}$ & $\begin{array}{l}\text { - Befriends others different } \\
\text { than self } \\
\text { - Makes new friends } \\
\text { - Gets to know more } \\
\text { people } \\
\text { - Gets to meet more people }\end{array}$ & $\begin{array}{l}\text { - Chooses positive friends } \\
\text { - Closer friendships } \\
\text { - Socializes more with peers } \\
\text { - More accepting of others } \\
\text { - Higher trust with teammates }\end{array}$ \\
\hline $\begin{array}{l}\text { Improved running } \\
\text { and motivation to } \\
\text { run }\end{array}$ & $\begin{array}{l}\text { - Improved running } \\
\text { - Faster runner }\end{array}$ & - Motivation to run & $\begin{array}{l}\text { - Wants to keep running } \\
\text { - Wants to do another } 5 \mathrm{k} \\
\text { - Strives do more } \\
\text { physically }\end{array}$ & $\begin{array}{l}\text { - Found an enjoyable activity } \\
\text { - More active mindset } \\
\text { - Active behavior motivates } \\
\text { younger kids }\end{array}$ \\
\hline $\begin{array}{l}\text { Standing up for self } \\
\text { and others }\end{array}$ & - Stand up for myself & $\begin{array}{l}\text { - Standing up for self } \\
\text { - Pride to be stand-byer } \\
\text { - Stand up for new kids }\end{array}$ & $\begin{array}{l}\text { - Supporting a girl who } \\
\text { was bullied }\end{array}$ & $\begin{array}{l}\text { - Confidence to stand up for self } \\
\text { - Supporting peers } \\
\text { - Persuade others to do right thing }\end{array}$ \\
\hline $\begin{array}{l}\text { Setting and } \\
\text { accomplishing goals }\end{array}$ & $\begin{array}{l}\text { - Completing each task } \\
\text { before moving on } \\
\text { - It is not about winning }\end{array}$ & & & $\begin{array}{l}\text { - Setting goals } \\
\text { - Greater commitment } \\
\text { - Works toward a greater goal }\end{array}$ \\
\hline
\end{tabular}

and nutritional health connote concrete behaviors, girls' responses are consistent with their developmental level.

Elle shared a change in physical activity, "Now I get outside a lot more. Like, I'll run around the yard, catch frogs, climb trees." Malia said, "I've been more active since I came to Girls on the Run because I used to do like 2 to 4 laps ... and since I came to Girls on the Run, I got 18 laps and the fact that I have asthma, I was really surprised." A coach/teacher noted, “. . . a girl was always tired in class and would fall asleep ... during the healthy habits lessons, we talked about how much sleep we should get . . . it was from this lesson that she realized she could choose to go to bed earlier." A caregiver shared a heartfelt example: "Makaila is in special education ... they're separated from the general population . . . and with Girls on the Run they're introduced into the general population. She lives without a label in Girls on the Run and that's really important, not to be labeled. In Girls on the Run, with the volunteers, coaches, teachers . . . everyone takes it away. It's gone, it's lifted."

\section{Community Impact Project}

The concept of an attitude of gratitude by contributing to one's community is addressed in 5 lessons of this program's curriculum. The culminating activity is implementing a community impact project, which is an index of contribution in the program philosophy. Sixteen coaches completed the online survey about their team's project, and girls, coaches, and caregivers in the focus groups described what girls learned from this experience.

Girls chose projects designed to benefit 5 causes, including animals, environment, hospital, school, and other. Four teams completed projects to provide support for people dealing with illness or injury. They collected donations or designed cards to be given to individuals in the hospital. One of these teams chose to collect toys, books, and stuffed animals to donate to a children's hospital after a team member shared a personal experience with long-term illness. Another 4 teams implemented projects concerning animal welfare. These involved gathering donations for animal shelters and advocating for animal adoption. Four teams chose to make a difference in their schools by implementing projects that showed appreciation of teachers and staff. Two teams collected and donated healthy snacks to food banks, and 2 teams made an environmental difference by cleaning up and beautifying their schools and communities.

Girls in the focus groups reported several benefits of completing community impact projects, and coaches provided convergent evidence of positive outcomes. They explained that involvement introduced them to issues of social justice. One girl said of her team's experience, "We learned that some people . . . like, they live 
Table 4 Focus Group Responses for Healthy Habits Learned Through Participating in Girls on the Run

\begin{tabular}{|c|c|c|c|c|}
\hline $\begin{array}{l}\text { Higher-order } \\
\text { theme }\end{array}$ & $\begin{array}{l}\text { Girls: lower-order } \\
\text { themes }\end{array}$ & $\begin{array}{l}\text { Coaches: lower-order } \\
\text { themes }\end{array}$ & $\begin{array}{l}\text { Caregivers: } \\
\text { lower-order themes }\end{array}$ & $\begin{array}{l}\text { School personnel: } \\
\text { lower-order themes }\end{array}$ \\
\hline Physical health & $\begin{array}{l}\text { - Exercising } \\
\text { - Better hygiene (eg, brush } \\
\text { hair, brush teeth) } \\
\text { - Play outside more } \\
\text { - How to stay fit } \\
\text { - Do stretching if sitting } \\
\text { - Skip, walk, and jump } \\
\text { - Run at home } \\
\text { - More active } \\
\text { - Improved running }\end{array}$ & $\begin{array}{l}\text { - More physical activity } \\
\text { - Better hygiene (eg, brush } \\
\text { teeth, self-care) } \\
\text { - Better sleep habits } \\
\text { - Running a 5k } \\
\text { - Joined school track team } \\
\text { - Slimming down } \\
\text { - Improving in running } \\
\text { - Walking changed to } \\
\text { running }\end{array}$ & $\begin{array}{l}\text { - Physical activity level } \\
\text { - Running more } \\
\text { - More physically active } \\
\text { - Be physically fit } \\
\text { - Active every day } \\
\text { - Go to sleep earlier } \\
\text { - Better hygiene } \\
\text { (eg, brush teeth, shower } \\
\text { everyday) }\end{array}$ & $\begin{array}{l}\text { - Exercising } \\
\text { - Active way of being } \\
\text { together } \\
\text { - Lifelong physical activity } \\
\text { - Movement } \\
\text { - Physical activities }\end{array}$ \\
\hline Nutrition & $\begin{array}{l}\text { - Healthy eating/foods } \\
\text { - Getting more protein } \\
\text { - Look at nutrition facts } \\
\text { - More veggies/fruits } \\
\text { - Not eat junk food } \\
\text { - Healthy snacks }\end{array}$ & $\begin{array}{l}\text { - Healthy plate } \\
\text { - Healthy snacks } \\
\text { - Healthy eating habits } \\
\text { - Healthy drink choices } \\
\text { - Drinking water } \\
\text { - Healthy eating }\end{array}$ & $\begin{array}{l}\text { - Healthier eating } \\
\text { - Drinking more water } \\
\text { - Preparing meals } \\
\text { - Makes healthy food } \\
\text { choices } \\
\text { - Goes food shopping to } \\
\text { eat healthier }\end{array}$ & $\begin{array}{l}\text { - Learning healthier snack } \\
\text { alternatives } \\
\text { - More aware of good } \\
\text { nutrition } \\
\text { - Choosing healthier foods } \\
\text { - Drinking more water } \\
\text { - Eating more fruit }\end{array}$ \\
\hline Emotional health & & $\begin{array}{l}\text { - Deals with peer pressure } \\
\text { - Handling anger } \\
\text { - Reduced anxiety } \\
\text { - Greater confidence } \\
\text { - Inner beauty } \\
\text { - Self-acceptance } \\
\text { - Healthy body image }\end{array}$ & $\begin{array}{l}\text { - Stronger emotionally } \\
\text { - Channel emotions in a } \\
\text { healthy way } \\
\text { - Not as impulsive } \\
\text { - Happier with self } \\
\text { - Positive body image } \\
\text { - Critical of media images }\end{array}$ & $\begin{array}{l}\text { - Body awareness } \\
\text { - Managing stress } \\
\text { - Okay to take time for self } \\
\text { - Okay to have difficult } \\
\text { feelings }\end{array}$ \\
\hline Mental health & & $\begin{array}{l}\text { - Increased motivation } \\
\text { - Love running } \\
\text { - Wants to keep running } \\
\text { - Setting goals }\end{array}$ & $\begin{array}{l}\text { - Accomplishing goal } \\
\text { increases self-esteem }\end{array}$ & - Goal setting \\
\hline Social health & & $\begin{array}{l}\text { - Connecting with people } \\
\text { - Bonding with girls } \\
\text { - Encouraged by girls } \\
\text { - Teaching others healthy } \\
\text { habits }\end{array}$ & $\begin{array}{l}\text { - Has a strong core of } \\
\text { friends } \\
\text { - Positive peer influence } \\
\text { to be healthy }\end{array}$ & $\begin{array}{l}\text { - Enjoy social aspects of } \\
\text { running } \\
\text { - Connecting face-to-face } \\
\text { - Looking after each other } \\
\text { - Learning to communicate }\end{array}$ \\
\hline
\end{tabular}

in poverty. I don't know how to say it." This girl's difficulty putting her experience into words suggests that such projects have the potential to expose participants to the less-pleasant realities of their communities. Other girls said that doing community projects helped them think more about other people's needs, suggesting that girls can develop a sense of empathy and sympathy through the program. Coaches suggested that girls developed empathy through involvement in their projects. One coach, whose team donated items to a children's hospital, described a positive change in sense of empathy, "They understood this could be any of us . . . anything could happen." Coaches reported that girls realized everyone has the potential to make positive contributions to society. As one coach put it, girls realized, "just little things can make a huge difference in someone's life."

\section{5k Season-Ending Event}

Of the 203 girls in our longitudinal sample, 167 or $82.3 \%$ completed the culminating $5 \mathrm{k}$. Coaches disclosed that some absences were due to issues of transportation, illness, injury, or family obligations.

\section{Discussion}

The purpose of our study was to evaluate the effectiveness of Girls on the Run in promoting positive youth development. We extended past evaluation studies in several ways by including a longitudinal design, quantitative and qualitative methods, constructs and measures that align with the program philosophy, and multiple stakeholder groups to share perspectives on program impact. Collective findings show that Girls on the Run is effective in attaining its goals of enhancing girls' social, psychological, and physical attributes and behaviors, which are compatible with PAPYD program objectives. In the following paragraphs, we systematically discuss key findings, link findings to program features that may explain impact, and offer implications for school-based and out-of-school-time physical activity programs.

The strongest findings emerged for girls who entered the program with below-average scores. Meaningful, and in some cases, dramatic improvement from preseason to postseason were observed for competence, confidence, connection, character, and caring, as well as for physical activity and sedentary behavior. Physical activity improved from 3.0 to 4.4 days per week of $\geq 60$ minutes per day-a $42 \%$ increase-and was sustained at follow-up. Hours of TV watching and playing video/computer games for nonschoolwork (ie, sedentary behavior) each decreased by $20 \%$ from preseason to postseason and remained stable at follow-up. This decrease in sedentary behavior is meaningful because of public health efforts to increase physical activity while simultaneously aiming to reduce TV watching and video game playing (31). Girls on the Run was especially effective for girls who 
need it the most-girls who indicated at the outset that they do not feel they do physical activities as well as others their age, find it harder to make friends, and feel less happy with themselves as a person benefited from skill-building lessons and positive social relationships afforded from participating in Girls on the Run. Simpkins (35) suggests that organized activities can play a compensatory role for youth who are more fragile relative to peers in personal and social attributes, leading to stronger program effects. Our social, emotional, and behavioral findings for girls starting lower than their peers at the start of the program on the Five Cs and physical activity (and higher on sedentary behaviors) are supported in other studies indicating that youth who have the most to benefit from positive sport experiences show the greatest gains $(1,36,37)$.

Girls who scored below the preseason average on particular variables also significantly improved from postseason to 3-month follow-up for perceived social competence, physical appearance, and classmate support, and global self-esteem. This finding was curious because follow-up assessments typically show retention of improved scores from pre to post because there is no further exposure to coaches, lessons, and activities. Simpkins (35) refers to this phenomenon of continued improvement after the end of a program as a "sleeper effect"-when effects emerge later or become larger over time (ie, continued improvement from post to follow-up). Girls on the Run spans 2 sessions weekly for 10 weeks, totaling 20 lessons and a culminating 5k. For girls starting below average, season-long improvements that continued to grow after the program ended may be an index of sleeper effects for competence, confidence, and connection. Improvement after lessons ended means these beliefs and behaviors might require even more time for the "lightbulb to come on" in children as young as 810 years old. Girls may encounter experiences that prompt use of learned skills in the program that may be reinforced by parents or friends, which in turn contributes to continued growth and development.

For the entire sample, statistically significant increases but small effect sizes emerged for indices of confidence and connection. Simpkins (35) suggests that a small effect size may still be meaningful due to the cumulative influence of multiple contexts (schools, families, and peers) on youth development and the relative time youth spend in these contexts (5). Given that youth typically spend a larger percentage of time in home and school settings, our findings may signify a positive effect of participating in a 10-week PA-PYD program. For other constructs, such as perceived physical and social competence and physical activity, preseason scores were relatively high (or low in the case of TV and video/computer games), which may have left little room to improve. Physical activity frequency was 4.9 days per week and TV and video/computer game playing were each only 1.1 hours per day. According to Simpkins (35), for some behaviors a positive effect may be maintaining relatively high levels that are prone to decline over time. Over the late childhood years, perceived competence and physical activity tend to show a downward trend for girls as they approach or go through puberty and make a transition to junior high school (22). Thus, stable high scores on variables that are potentially vulnerable to decline over time may represent a positive finding.

Evidence of season-long improvements in the Five Cs and physical activity also emerged from focus group responses by girls, coaches, caregivers, and school personnel. Use of multiple stakeholders enabled varying perspectives and evidence of converging data. Responses corroborated positive change in physical and social competence (eg, improved running, improved social behaviors), confidence (eg, acceptance of self, feelings of empowerment), connection (eg, improving friendships, accepting others), and character and caring behaviors (eg, standing up for self and others). Stakeholders were unanimous in characterizing Girls on the Run as promoting a holistic healthy lifestyle, by describing seasonlong positive change in physical health (eg, more active, staying fit), nutrition (eg, not eating junk food), emotional health (eg, controlling anger, handling peer pressure), mental health (eg, increased motivation, setting goals), and social health (eg, stronger core of friends). Embracing a physically active lifestyle at a young age is important for maximizing positive and reducing negative health outcomes later in life $(29,32)$.

Information about the community impact project revealed that Girls on the Run is successful in promoting a sense of civic engagement and positive attributes, such as character, empathy, and sympathy. Girls are given opportunities to work cooperatively, develop an awareness of other people's circumstances, and recognize their potential to make a positive difference in the world. Girls supported individuals in need (eg, sick children in the hospital) and contributed to their school, community, and society (eg, food bank donations, environmental awareness). Girls learned the value of helping others and recognizing the joy brought to others from authentic kindness, philanthropy, and compassion. Implementing a community impact project is an innovative component of this PAPYD program and consistent with recommendations for effective PYD programs (13). Based on coaches' survey information and focus group data from girls, coaches, and caregivers, the community project was a memorable and enduring experience for the girls.

The $5 \mathrm{k}$ event reflects the cumulative physical activity training throughout the 10-week season and an important index of physical competence attained from participation (45). To prepare for this physical activity goal, lessons include learning to pace, building strength and stamina, and embracing a philosophy of "it's all about finishing" and not what place or time one achieves. Girls are encouraged to keep moving even if they walk, hop, jump, or skip in addition to running. A practice $5 \mathrm{k}$ is included during week 8, and girls are encouraged to give their best effort and apply learned skills such as changing negative to positive self-talk. At the end of the practice $5 \mathrm{k}$, girls identify a personal goal to prepare for the end-of-season $5 \mathrm{k}$. As seen, $82 \%$ of the girls in our sample completed the $5 \mathrm{k}$, demonstrating that the intentional curriculum was effective in developing skills for successfully achieving the capstone physical activity goal.

Collectively, findings provide evidence that Girls on the Run is having a positive impact on girls' social, psychological, and physical behaviors. We attribute evidence of effectiveness to the intentional curriculum and coach training - the processes that form the foundation of the program. The curriculum that is deliberately structured to provide skill-building opportunities and intentionality of lessons means that coaches' behaviors explicitly focus on helping girls achieve PYD goals $(13,25,33)$. Coach training is systematic and interactive, including in-person workshops, online training, and access to additional resources. The focus is achieving high-quality delivery by assisting coaches to teach social, emotional, and physical skills and behaviors. This is accomplished by a focus on building positive relationships, creating a positive inclusive environment, and emphasizing a mastery climate-which map onto effective social-contextual features of PYD programs $(13,25,33)$. The curriculum and coach training align with the mission, vision, and core values of the program and were developed based on evidence-based best practices in physical activity settings. Thus, favorable outcomes obtained from a longitudinal 
design, quantitative and qualitative methods, and multiple stakeholders reflect efforts to successfully implement the intentional curriculum by coaches trained to deliver the lessons with fidelity.

Girls on the Run collaborates with schools to offer programming and resources that promote healthy youth development, including social and emotional learning and physical activity. This school-community partnership is compatible with the Whole School, Whole Community, Whole Child Model (3) that advocates educators, communities, families, and policy makers work together to ensure children are healthy, safe, engaged, supported, and challenged. This approach is also consistent with the goals of the National Physical Activity Plan (29), which focuses on strategies to increase physical activity and holistic health outcomes in multiple societal sectors including educational and community settings. The synergy between schools and Girls on the Run to offer a PA-PYD program featuring an intentional curriculum delivered by trained coaches is a strong example of meeting the goals of National Physical Activity Plan and Whole School, Whole Community, Whole Child Model.

Along with evidence that Girls on the Run is an effective PAPYD program, we note some limitations and future research directions. First, implementation feasibility resulted in 3 councils being selected. It is possible that participants from councils that have fewer years of delivering the curriculum and/or less experienced coaches may not have shown the same degree of positive results. Second, the Five Cs, physical activity, and sedentary behavior were assessed using self-report, which may have resulted in some socially desirable scores. Thus, qualitative interviews were invaluable to offer open-ended responses about attitudes and behaviors learned in Girls on the Run. To this point, we relied on volunteers to participate in focus groups. Individuals may have been willing to dedicate time and energy in an interview because of favorable impressions of the program. This may explain why adverse program effects were not uncovered. Future research might recruit caregivers who hold varying perspectives about the program, which would potentially uncover areas for improving curricula and delivery. Third, it is possible that a self-selection bias exists in which girls and parents who choose to participate in Girls on the Run are different than those who choose to participate in other after-school activities. Finally, focus groups revealed that caregivers held favorable impressions about Girls on the Run but were not articulate about specific lessons that influenced their children's positive outcomes. As parents are a primary source for reinforcing lessons learned by their children in out-ofschool-time programs, future research might focus on how parents can be best informed about program goals, curricular lessons, and core values to strengthen program impact.

In conclusion, using a longitudinal design, measures compatible with the Five $C s$ philosophy, quantitative and qualitative methods, and multiple stakeholders' perspectives, findings provide data-based evidence that Girls on the Run is effective in improving physical, social, and emotional behaviors, with particularly strong effects for girls who started the season with lower scores on the Five $C s$ and physical activity and higher scores on sedentary behavior. The intentional curriculum and coach training help explain why favorable findings emerged and suggest they can serve as exemplars for other after-school physical activity programs. We end with a compelling quote by a girl, written in response to an open-ended survey question, "Is there anything else you would like to share about your experiences in Girls on the Run?" She wrote: "If you are a girl that is bad at making friends, nobody listens or understands how you're feeling, and you sit alone every day ... that was me. Then I joined Girls on the Run. IT CHANGED MY LIFE. Now I have way more than one friend by the second week of school and I have people who UNDERSTAND ME. I used to yell out when I got very angry, now I can hold in my temper. I love my life because of Girls on the Run."

\section{Notes}

${ }^{1}$ Most of Girls on the Run's programs are located in schools, but they also offer some programs at nonschool sites.

${ }^{2}$ Significant multivariate $F$ values $=5.64,3.58$, and 7.56. Significant follow-up $t$ values $=2.50$ to 3.90 .

${ }^{3}$ Significant multivariate $F$ values $=7.49$ to 21.59 . Significant follow-up $t$ values $=2.29$ to 6.61 .

${ }^{4}$ Names used are pseudonyms.

\section{Acknowledgments}

This research was supported by a grant awarded to the first author by Reemprise Fund, Foundation for the Carolinas. The authors thank Hailee Moehnke for valuable assistance with data collection, entry, and analysis; Rebecca Nelson, Lauren Wakabayashi, and Jill Kochanek for survey data entry; Sonali Rajan for data collection; and Emilio Ferrer for statistical advice. We are very grateful to Girls on the Run International for enabling us to conduct a study of this magnitude and for constant support and trust in our work. We give a special shout-out to Allie Riley, Senior Vice President of Programming and Evaluation, who served as a liaison with councils and facilitated our research efforts. We are thankful to the council directors, coaches, school personnel, and caregivers for their investment of time in our study. Finally, we are indebted to all the girls who completed surveys, participated in focus groups, and shared their experiences in Girls on the Run, which reinforced our desire and life's work to make a difference in young girls' lives.

\section{References}

1. Anderson-Butcher D, Riley A, Amorose A, Iachini A, WadeMdivanian R. Maximizing youth experiences in community sport settings: the design and impact of the life sports camp. J Sport Manage. 2014;28:236-49. doi:10.1123/jsm.2012-0237

2. Armour K, Sandford R. Positive youth development through an outdoor physical activity programme: evidence from a four-year evaluation. Educ Rev. 2013;65:85-108. doi:10.1080/00131911.2011. 648169

3. ASCD, CDC. Whole School, Whole Community, Whole Child: A Collaborative Approach to Learning and Health [Internet]. Alexandria, VA: ASCD; 2014. https://www.cdc.gov/healthyschools/wscc/. Accessed July 18, 2018.

4. Bengsbo J, Krustrup P, Duda J, et al. The Copenhagen Consensus Conference 2016: children, youth, and physical activity in schools and during leisure time. British J Sports Med. 2016;50(19):1177-8. doi:10.1136/bjsports-2016-096325

5. Bronfenbrenner U, Morris PA. The ecology of developmental processes. In: Damon W, series editor, Lerner RM, volume editor. Handbook of Child Psychology: Theoretical Models of Human Development. 5th ed. New York, NY: Wiley; 1998, pp. 993-1028.

6. Bruening JE, Dover KM, Clark BS. Preadolescent female development through sport and physical activity: a case study of an urban after-school program. Res Q Exerc Sport. 2009;80:87-101. PubMed ID: 19408471 
7. Brustad RJ, Vilhjalmsson R, Fonseca AM. Organized sport and physical activity promotion. In: Smith AL, Biddle SJH, editors. Youth Physical Activity and Sedentary Behavior: Challenges and Solutions. Champaign, IL: Human Kinetics; 2008, pp. 351-75.

8. Centers for Disease Control and Prevention (CDC). Youth Risk Behavior Survey [Internet]. Washington, DC: CDC; 2017. https://www.cdc. gov/features/dsyouthmonitoring/index.html. Accessed July 18, 2018.

9. Cohen JA. A power primer. Psych Bull. 1992;112:155-9. doi:10. 1037/0033-2909.112.1.155

10. DeBate R, Zhang Y, Thompson SH. Changes in commitment to physical activity among 8-11-year-old girls participating in a curriculum-based running program. J Health Educ. 2007;38: 276-83.

11. Dzewaltowski DA. Community out-of-school physical activity promotion. In: Smith AL, Biddle SJH, editors. Youth Physical Activity and Sedentary Behavior: Challenges and Solutions. Champaign, IL: Human Kinetics; 2008, pp. 377-401.

12. Dzewaltowski DA, Rosenkranz RR. Youth development: an approach for physical activity behavioral science. Kinesiology Rev. 2014;3:92-100. doi:10.1123/kr.2014-0042

13. Eccles JS, Gootman JA. Features of positive developmental settings. In: Eccles JS, Gootman JA, editors. Community Programs to Promote Youth Development. Washington, DC: National Academy Press; 2002, pp. 86-118.

14. Eisenberg N, Fabes RA, Murphy B, Karbon M, Smith M, Maszk P. The relations of children's dispositional empathy-related responding to their emotionality, regulation, and social functioning. Dev Psych. 1996;32:195-209. doi:10.1037/0012-1649.32.2.195

15. Gabriel KP, DeBate RD, High RR, Racine EF. Girls on the run: a quasi-experimental evaluation of a developmentally focused youth sport program. J Phys Act Health. 2011;8:S285-94. PubMed ID: 28829708 doi:10.1123/jpah.8.s2.s285

16. Gano-Overway LA, Newton M, Magyar TM, Fry MD, Kim M, Guivernau MR. Influence of caring youth sport contexts on efficacyrelated beliefs and social behaviors. Dev Psych. 2009;45:329-40. doi:10.1037/a0014067

17. Geldhof GJ, Bowers EP, Boyd MJ, et al. Creation of short and very short measures of the five Cs of positive youth development. J Res Adolesc. 2013;24:163-76. doi:10.1111/jora.12039

18. Geldhof GJ, Bowers EP, Kiely Mueller M, et al. Longitudinal analysis of a very short measure of positive youth development. J Youth Adolesc. 2014;43:933-49. PubMed ID: 24557779 doi:10. 1007/s10964-014-0093-z

19. Harter S. Self-Perception Profile for Children: Manual and Questionnaires. Denver, CO: University of Denver; 2012.

20. Harter S. Social Support Scale for Children: Manual and Questionnaires. Denver, CO: University of Denver; 2012.

21. Hillman CH, Erickson KI, Hatfield BD. Run for your life! Childhood physical activity effects on brain and cognition. Kin Review. 2017; 6:12-21.

22. Horn TS. Developmental perspectives on self-perceptions in children and adolescents. In: Weiss MR, editor. Developmental Sport and Exercise Psychology: A Lifespan Perspective. Morgantown, WV: Fitness Information Technology; 2004, pp. 101-43.

23. Jones S, Brush K, Bailey R, et al. Navigating SEL from the inside out. Looking inside and across 25 leading SEL programs: a practical resource for schools and OST providers [Internet]. Cambridge, MA: Harvard Graduate School of Education; 2017. http://easel.gse. harvard.edu/. Accessed July 18, 2018.

24. Krueger RA, Casey MA. Focus Groups: A Practical Guide for Applied Research. 3rd ed. Thousand Oaks, CA: Sage; 2000.
25. Lerner RM, Lerner JV. Toward a new vision and vocabulary about adolescence: theoretical, empirical, and applied bases of a "Positive Youth Development" perspective. In: Balter L, Tamis-LeMonda CS, editors. Child Psychology: A Handbook of Contemporary Issues. New York, NY: Psychology Press; 2006, pp. 445-69.

26. Li W, Wright PM, Rukavina PB, Pickering M. Measuring students' perceptions of personal and social responsibility and the relationship to intrinsic motivation in urban physical education. $J$ Teach Phys Educ. 2008;27:167-78. doi:10.1123/jtpe.27.2.167

27. Martin JJ, Waldron J, McCabe A, Choi YS. The impact of "Girls on the Run" on self-concept and fat attitudes. J Clin Sport Psych. 2009;3:127-38. doi:10.1123/jesp.3.2.127

28. McCombs JS, Whitaker A, Yoo PY. The Value of Out-ofSchool Time Programs. Santa Monica, CA: RAND Corporation; 2017.

29. National Physical Activity Plan Alliance. National Physical Activity Plan [Internet]. Columbia, SC: Author; 2016. www. physicalactivityplan.org. Accessed July 18, 2018.

30. Petitpas AJ, Cornelius AE, Van Raalte JL, Jones T. A framework for planning youth sport programs that foster psychosocial development. Sport Psych. 2005;19:63-80. doi:10.1123/tsp.19.1.63

31. Physical Activity Guidelines Advisory Committee. 2018 Physical Activity Guidelines Advisory Committee Scientific Report. Washington, DC: USDHHS; 2018.

32. Physical Activity Guidelines for Americans Midcourse Report. Physical Activity Guidelines for Americans Midcourse Report: Strategies to Increase Physical Activity among Youth. Washington, DC: USDHHS; 2012.

33. Roth JL, Brooks-Gunn J. What exactly is a youth development program? Answers from research and practice. Applied Dev Sci. 2003;7:94-111. doi:10.1207/S1532480XADS0702_6

34. Sifers SK, Shea DN. Evaluations of girls on the run/girls on track to enhance self-esteem and well-being. J Clin Sport Psych. 2003;7: 77-85. doi:10.1123/jcsp.7.1.77

35. Simpkins SD. When and how does participating in an organized afterschool activity matter? Applied Dev Sci. 2015;19:121-6. doi:10.1080/ 10888691.2015.1056344

36. Smoll FL, Smith RE, Barnett NP, Everett JJ. Enhancement of children's self-esteem through social support training for youth sport coaches. J Applied Psych. 1993;78:602-10. doi:10.1037/0021-9010. 78.4.602

37. Ullrich-French S, Cole AN. Exploring participant characteristics in an assessment of changes in psychosocial outcomes in a physical activity-based positive youth development programme for girls. Intl J Sport Ex Psych. 2018;16:535-54. doi:10.1080/1612197X.2016. 1275740

38. Ullrich-French S, McDonough MH, Smith AL. Social connection and psychological outcomes in a physical activity-based youth development setting. Res $Q$ Exerc Sport. 2012;83:431-41. PubMed ID: 22978193 doi:10.1080/02701367.2012.10599878

39. US Department of Health and Human Services. 2008 Physical Activity Guidelines for Americans. Washington, DC: US Department of Health and Human Services; 2008.

40. Walsh DS, Ozaeta J, Wright PM. Transference of responsibility model goals to the school environment: exploring the impact of a coaching club program. Phys Educ Sport Pedagogy. 2010;15:15-28. doi:10.1080/17408980802401252

41. Weiss MR. Positive youth development through physical activity: progress, puzzles, and promise. In: Horn TS, Smith AL, editors. Advances in Sport and Exercise Psychology. 4th ed. Champaign, IL: Human Kinetics; 2019, pp. 483-502. 
42. Weiss MR, Bolter ND, Kipp LE. Evaluation of The First Tee in promoting positive youth development: group comparisons and longitudinal trends. Res $Q$ Exerc Sport. 2016;87:271-83. PubMed ID: 27142299 doi:10.1080/02701367.2016.1172698

43. Weiss MR, Kipp LE, Bolter ND. Training for life: optimizing positive youth development through sport and physical activity. In: Murphy SM, editor. Handbook of Sport and Performance Psychology. New York, NY: Oxford University Press; 2012, pp. 448-75.
44. Weiss MR, Stuntz CP, Bhalla JA, Bolter ND, Price MS. 'More than a game': impact of The First Tee life skills programme on positive youth development: project introduction and year 1 findings. Qual Res Sport Exerc Health. 2013;5:214-44. doi:10.1080/2159676X. 2012.712997

45. Weiss MR, Wiese-Bjornstal DM. Promoting positive youth development through physical activity. Pres Council Phys Fitness Sports Res Digest. 2009;10(3):1-8. 